\title{
Experimental diopsidite: Implications for natural diopsidite genesis through fluid-melt-mantle peridotite reaction
}

\author{
Anastassia Y. Borisova $^{1,2}\left(\mathbb{C}^{\circ} \cdot\right.$ Georges Ceuleneer $^{1} \cdot$ Nail R. Zagrtdenov $^{3} \cdot$ Oleg G. Safonov $^{4,2} \cdot$ Michael J. Toplis $^{5}$
}

Received: 19 June 2020 / Accepted: 21 July 2021

(c) The Author(s), under exclusive licence to Springer-Verlag GmbH Austria, part of Springer Nature 2021

\begin{abstract}
Occurrences of diopsidites, rocks made predominantly of gem-like diopside whose composition precludes a purely igneous origin, allow tracking the pathway of high-temperature fluids and fluid-saturated melts in the oceanic lithosphere in vicinity of the mantle-crust transition zone (the Moho) and the adjacent mantle in an oceanic setting. We have experimentally explored the origin of the mantle diopsidites by reacting serpentinite with synthetic haplobasaltic glass (corresponding to anorthite-diopside eutectic at $0.1 \mathrm{MPa}$ pressure) at 900 and $1250{ }^{\circ} \mathrm{C}$, and $0.2 \mathrm{GPa}$ pressure for $120 \mathrm{~h}$. At $900{ }^{\circ} \mathrm{C}$, no reaction is observed in the sample; in contrast, in the experimental runs heated to $1250{ }^{\circ} \mathrm{C}$, we distinguish two mineral associations (1) early $\mathrm{Al}$-poor diopside $\left[\mathrm{Mg} \#=\mathrm{Mg} /(\mathrm{Mg}+\mathrm{Fe})=99 \pm 1 ; \mathrm{Al}_{2} \mathrm{O}_{3}=1.9 \pm 1.6 \mathrm{wt} \%\right]$ with the diopside-hosted forsterite $\left(\mathrm{Fo}_{99.2} \pm 0.1\right)$ inclusions and (2) late Al-enriched diopside ( $\left.\mathrm{Mg} \#=98 \pm 1 ; \mathrm{Al}_{2} \mathrm{O}_{3}=3.7 \pm 2.8 \mathrm{wt} \%\right)$. Our experiments confirm that mantle diopsidites can be produced at $\geq 1100{ }^{\circ} \mathrm{C}$ in response to partial melting of hydrated peridotite (serpentinite) in the presence of haplobasaltic melt and aqueous fluid at the conditions typical of the mantle-crust transition zone and the shallow mantle beneath oceanic spreading ridges.
\end{abstract}

Keywords Diopsidite $\cdot$ Oceanic lithosphere $\cdot$ Hydrated peridotite $\cdot$ Mantle-crust transition zone $\cdot$ Melt-rock reaction experiment

\section{Introduction}

Diopsidites were discovered in the Oman ophiolite and interpreted as crystallization products resulting from the percolation of hydrothermal fluids in mantle peridotite

Editorial handling: A. R. Chakhmouradian

Anastassia Y. Borisova

anastassia.borisova@get.omp.eu

1 Géosciences Environnement Toulouse (GET), Université de Toulouse, CNRS, 14 Avenue E. Belin, 31400 Toulouse, IRD, France

2 Geological Department, Lomonosov Moscow State University, MGU, Vorobievu Gori, 119991 Moscow, Russia

3 CanmetMINING, Natural Resources Canada, 555 Booth Street, Ottawa, ON K1A 0G1, Canada

4 Korzhinskii Institute of Experimental Mineralogy, 142432 Chernogolovka, Moscow region, Russia

5 Institut de Recherche en Astrophysique Et Planétologie (IRAP) UPS OMP - CNRS- , CNES, 14 Avenue E. Belin, 31400 Toulouse, France at high temperatures (Python et al. 2007a,b). These rocks are made up predominantly of diopside $[0.95<\mathrm{Mg} /$ $(\mathrm{Mg}+\mathrm{Fe})<1]$ and minor Mg-rich (Fo $>95$ mol\%) olivine. The diopsidites form dykes hosted by peridotites in the lithospheric part of ophiolites (Python et al. 2007a; Akizawa and Arai 2014). Veins composed mainly of diopside with associated chromite, Fe-Ni-Co metal, silica and troilite occur in lunar soil samples collected by the Apollo 17 mission at the base of the Sculptured Hills and appear to result from intrusion and crystallization of fluid (Irving et al. 1974). The source of the fluid is considered as enigmatic. MARID suite consisting of varying proportions of mica, amphibole, rutile, ilmenite and diopside has been distinguished by Dawson and Smith (1977) within kimberlite pipes. In the oceanic mantle-crust transition zone, diopside is present as scattered crystals in dunites and as inclusions in chromites at the same setting (Borisova et al. 2012; Rospabé et al. 2017, 2019). Additionally, rare occurrences of plagioclase diopsidites, made of equal proportions of diopside and pure anorthite, have also been reported in the dunitic transition zone (Python et al. 2007a) and in the ophiolitic and modern oceanic crust 
(Vanko and Laverne 1998; Akizawa et al. 2011; Akizawa and Arai 2014). Mantle diopsidites have (not foliated) metasomatic textures contrasting with igneous textures and comparable to those of metasomatic skarns or rodingites frequently present in serpentinite bodies within the ophiolitic crust. The diopsidites frequently appear as dykes, with a few $\mathrm{mm}$ to few tens of $\mathrm{cm}$ wide transitional zones, which contain high amounts of hydrous minerals, between the diopsidite and its host rock (Python et al. 2007a). The mechanism of the diopsidite rock formation was proposed to be crystallization from high temperature fluids intermediate between the silicate melts and supercritical water. These rocks were suggested to form due to high temperature circulation of seawater-derived hydrothermal or carbonated fluids at $>800{ }^{\circ} \mathrm{C}$ close to the mantle-crust transition zone (Python et al. 2007a). One argument for the hydrothermal origin of the water is the pronounced positive Eu anomaly in diopside crystals, showing that the fluid has leached gabbroic rocks en route to the Moho transition zone (Python et al. 2007a). However, the proposed mechanism requires a high waterto-rock ratio and may be unrealistic. Thus, it is still a matter of debate why predominant diopside crystallizes in the mantle to form diopsidite rocks. A revised formation mechanism of the high-Mg rock origin may now be proposed based on reactions documented at depths in the oceanic lithosphere (Benoit et al. 1999; Borisova et al. 2012; Rospabé et al. 2017, 2019; Zagrtdenov et al. 2018; Borisova et al. 2020, 2021), as well as based on experimental modeling of the proposed reactions at a pressure of $0.2 \mathrm{GPa}$.

\section{Experimental and analytical methods}

To experimentally model the petrogenesis of diopsidite rocks, we have used a similar design as that of Borisova et al. $(2020,2021)$ with a serpentinite cylinder in the upper part and haplobasaltic (i.e. the synthetic system of albiteanorthite-diopside, Barth 1962) glass powder in the lower part of an $\mathrm{Au}_{80} \mathrm{Pd}_{20}$ capsule. As starting materials, we used the synthetic haplobasalt (86.7-82.4 wt\%) and natural serpentinite (13.3-17.6 wt\%) (Table 1). These components have been chosen to model experimentally interaction between (i) a model silicate melt, which is formed due to partial melting of predominantly gabbroic crust enriched in anorthite and diopside, (ii) altered (hydrated or serpentinized) peridotite and (iii) an aqueous fluid. These experiments were designed to simulate the process of basaltic melt infiltration into serpentinite rock that does not necessarily reach equilibrium. Three experiments (P40, P41 and P41bis) with different basalt to serpentinite mass ratios (4.7-6.5; Table 2) were carried out at a pressure of 0.2
Table 1 Compositions (wt \%) of the starting materials

\begin{tabular}{|c|c|c|}
\hline Sample* & BAS & SERP \\
\hline $\mathrm{SiO}_{2}$ & 50.34 & 40.69 \\
\hline $\mathrm{TiO}_{2}$ & - & bdl \\
\hline $\mathrm{Al}_{2} \mathrm{O}_{3}$ & 15.38 & 0.88 \\
\hline $\mathrm{Fe}_{2} \mathrm{O}_{3} * *$ & - & 7.53 \\
\hline $\mathrm{MnO}$ & - & 0.11 \\
\hline $\mathrm{MgO}$ & 10.80 & 38.24 \\
\hline $\mathrm{CaO}$ & 23.48 & 0.06 \\
\hline $\mathrm{Na}_{2} \mathrm{O}$ & - & bdl \\
\hline $\mathrm{K}_{2} \mathrm{O}$ & - & bdl \\
\hline $\mathrm{P}_{2} \mathrm{O}_{5}$ & - & 0.05 \\
\hline LOI & - & 11.55 \\
\hline Total & 100.00 & 99.1 \\
\hline \multicolumn{2}{|l|}{$\underline{\mathrm{H}_{2} \mathrm{O} \text { total }}$} & 11.91 \\
\hline \multicolumn{3}{|c|}{$\begin{array}{l}{ }^{*} B A S \text { haplobasaltic powder, } \\
S E R P \text { serpentinite rock (TSL- } \\
19 \text { ), BDL values below detec- } \\
\text { tion limits. } L O I \text { loss on ignition }\end{array}$} \\
\hline \multicolumn{3}{|c|}{${ }^{* *}$ Total $\mathrm{Fe}$ quoted as $\mathrm{Fe}_{2} \mathrm{O}_{3}$} \\
\hline
\end{tabular}

GPa and temperature of $900{ }^{\circ} \mathrm{C}(\mathrm{P} 40)$ and $1250{ }^{\circ} \mathrm{C}(\mathrm{P} 41$ and $\mathrm{P} 41$ bis) using an internally heated gas pressure vessel (Safonov et al. 2014). The duration of experiments was $120 \mathrm{~h}$ for all runs. The pressure in the system was created by pure Ar gas. The experimental charge was heated in a furnace with two windings (to minimize any thermal gradient). The temperature was set and measured by a TRM101 OVEN controller through two S-type $\left(\mathrm{Pt}_{90} \mathrm{Rh}_{10}\right.$ versus $\left.\mathrm{Pt}_{100}\right)$ thermocouples. The thermocouples were mounted at the top and close to the bottom of the run hot spot to monitor the temperature gradient. The experiments were quenched by switching off the furnace. The pressure during the quench was kept constant down to $550{ }^{\circ} \mathrm{C}$, and then slowly released. The cooling rate from 1250 to $1000{ }^{\circ} \mathrm{C}$ was $167{ }^{\circ} \mathrm{C} / \mathrm{min}$, and then $90^{\circ} \mathrm{C} / \mathrm{min}$ from $900-1000{ }^{\circ} \mathrm{C}$ down to $550^{\circ} \mathrm{C}$. After the runs, the $\mathrm{Au}_{80} \mathrm{Pd}_{20}$ capsules were mounted in epoxy, cut in half using a diamond micro-saw, and then polished using $\mathrm{SiC}$ sand papers and diamond pastes.

The major experimental products (silicates and hydrous glasses) in the samples were identified using two scanning electron microscopes (SEM) JEOL JSM-6360 LV and Bruker TESCAN using energy-dispersive X-ray spectrometry (EDS). X-ray mapping of the experimental samples was performed using the electron microscopes. In order to perform the EDS mapping, the X-ray lines $(K \alpha)$ have been measured for the elements $\mathrm{Al}, \mathrm{Si}, \mathrm{Mn}, \mathrm{Fe}, \mathrm{Ca}$ and $\mathrm{Mg}$. Major and minor elements in the crystals and glasses were analyzed using a CAMECA SX-Five electron probe micro-analyser (EPMA) operated at $15 \mathrm{kV}$ and $20 \mathrm{nA}$; the analyzed surface area was $2 \mu \mathrm{m}^{2}$. The following synthetic and natural reference materials were used for the EPMA calibration: albite (for $\mathrm{Na}$ ), corundum (Al), wollastonite 
Table 2 Experimental sample description

\begin{tabular}{lllll}
\hline Sample & Conditions & Starting proportions* & $\begin{array}{l}\text { BAS melt to } \\
\text { SERP rock } \\
\text { ration }\end{array}$ & Final phases** \\
& $\mathrm{T}\left({ }^{\circ} \mathrm{C}\right), \mathrm{P}(\mathrm{GPa})$ & SERP / BAS $(\mathrm{wt} \%)$ & - & \\
\hline P40 & $900,0.2$ & $16.9 / 83.1$ & 4.93 & Dehydrated serpentinite and haplobasaltic glass \\
P41 & $1250,0.2$ & $13.3 / 86.7$ & 6.50 & Diopside, Mg-rich olivine: D1 and D2 \\
P41bis & $1250,0.2$ & $17.6 / 82.4$ & 4.69 & Diopside, Mg-rich olivine: D1 and D2 \\
\hline
\end{tabular}

*SERP serpentinite rock, $B A S$ haplobasaltic powder, $T$ temperature and $P$ pressure

*** The final mineral associations are represented by (i) D1: early Al-poor diopside-hosted forsterite inclusions together with (ii) D2: late Al-rich diopside composed by well-crystallized diopsidite with water fluid bubbles

( $\mathrm{Si}, \mathrm{Ca})$, sanidine $(\mathrm{K})$, pyrophanite $(\mathrm{Mn}, \mathrm{Ti})$, hematite $(\mathrm{Fe})$, periclase $(\mathrm{Mg}), \mathrm{Cr}_{2} \mathrm{O}_{3}(\mathrm{Cr})$ and $\mathrm{Ni}$ metal $(\mathrm{Ni})$. Peak and background counting times were $5 \mathrm{~s}$ for $\mathrm{Na}$ and $\mathrm{K}$ and $10 \mathrm{~s}$ for other major elements, whereas peak counting times were $120 \mathrm{~s}$ for $\mathrm{Cr}$ and $100 \mathrm{~s}$ for Ni. Resulting detection limits for $\mathrm{Cr}$ and $\mathrm{Ni}$ were $70 \mathrm{ppm}$ and $100 \mathrm{ppm}$, respectively. Silicate glass reference materials (MPIDING) glasses (ATHO-G, StHs6/80-G, T1-G, KL2-G, ML3B-G, GOR132-G, GOR128-G, Jochum et al. 2006) were analyzed as unknowns to monitor the accuracy of the major and minor $(\mathrm{Cr}, \mathrm{Ni})$ element analyses. The analysis of silicate reference materials allowed us to control precision for the major and minor element analyses to be within the limit of the analytical uncertainty (related to the count statistics). The accuracy, estimated on the reference glasses, ranged from 0.5 to $3 \%(1 \sigma \mathrm{RSD}=$ relative standard deviation), depending on the element contents in the reference glasses.

\section{Results}

Figure 1 (a-i) illustrates backscattered electron images and $\mathrm{X}$-ray mapping of the diopsidite samples (P40, P41 and $\mathrm{P} 41$ bis $)$. The $\mathrm{P} 40$ sample $\left(900^{\circ} \mathrm{C}\right)$ contains initial starting serpentinite rock and haplobasaltic glass with no reaction zone (Fig. 1d,g), whereas the recovered P41 and P41bis samples $\left(1250{ }^{\circ} \mathrm{C}\right)$ are almost monomineralic and comprise predominantly diopside (Fig. 1a-c, e-f, h-i). In the experimental diopsidites, two mineral associations were distinguished: (D1) early Al-poor diopside ( $\mathrm{Mg} \#=99 \pm 1$; $\left.\mathrm{Al}_{2} \mathrm{O}_{3}=1.9 \pm 1.5 ; \mathrm{Cr}_{2} \mathrm{O}_{3}=0.16 \pm 0.10 \mathrm{wt} \%\right)$ with inclusions of forsterite $\left(\mathrm{Fo}_{99.2 \pm 0.1}\right)$ (Fig. $\left.1 \mathrm{a}-\mathrm{c}, \mathrm{e}, \mathrm{h}, \mathrm{i}\right)$ and (D2) late Alrich diopside $\left(\mathrm{Mg} \#=98 \pm 1 ; \mathrm{Al}_{2} \mathrm{O}_{3}=3.7 \pm 2.8 \mathrm{wt} \%\right)$ forming a well-crystallized diopsidite matrix (Fig. 1a-b, f, i; Table 3). The size of the diopside crystals varies from 100 to several hundred $\mu \mathrm{m}$.

\section{Discussion}

Results of the P41 and P41bis runs demonstrate that haplobasaltic melt component reacts with dehydrated serpentinite at $1250{ }^{\circ} \mathrm{C}$ at conditions of saturation with aqueous fluid, whereas temperature of $900{ }^{\circ} \mathrm{C}$ was not sufficient to initiate the reaction. Numerous bubbles in experimental samples P41 and P41bis correspond to a fluid, consistent with water fluid saturation of the haplobasaltic melt at 0.2 GPa pressure. According to Benne and Behrens (2003), the saturation of haplobasaltic melt in anorthite-diopside system with aqueous fluid at $0.2 \mathrm{GPa}$ requires an $\mathrm{H}_{2} \mathrm{O}$ content of about $5 \mathrm{wt} \%$ in the melt; it is likely that the water saturation of the melt was developed progressively in response to the crystallization of anhydrous mineral. The conditions created in our experimental system at $1250{ }^{\circ} \mathrm{C}$ thus were close to aqueous fluid saturation due to serpentinite dehydration, especially at the final stages of the diopsidite crystallization. The localized occurrence of Mg-rich olivine inclusions in the low-Al diopside crystals (Fig. 1) corresponds to the emplacement of the former serpentinite zone, suggesting reaction of serpentinite with haplobasaltic melt and aqueous fluid to form forsterite and Al-poor diopside according to the following equation:

$$
\begin{aligned}
\mathrm{Mg}_{3} \mathrm{Si}_{2} \mathrm{O}_{5}(\mathrm{OH})_{4}[\text { Serp }] & +2 \mathrm{CaAl}_{0.74} \mathrm{Mg}_{0.63} \mathrm{Si}_{2} \mathrm{O}_{6.7}[\mathrm{HB}]=\mathrm{MgSiO}_{4}[\text { Fo }] \\
& +\mathrm{CaMgSi}_{2} \mathrm{O}_{6}[\mathrm{Di}]+\mathrm{CaAl}_{1.48} \mathrm{Mg}_{1.63} \mathrm{SiO}_{10.4}[R M] \\
& +2 \mathrm{H}_{2} \mathrm{O}[\text { Fluid }]
\end{aligned}
$$

where Serp is the principal serpentine mineral, $H B$ is haplobasaltic melt component, $F o$ is forsterite, $D i$ is diopside, $R M$ is a residual silicate (melt) component and Fluid is an aqueous fluid.

From experimental works of Yoder (1964) and Yoder and Tilley (1962), it is well-known that higher pressures widen the crystallization field of diopside in haplobasaltic 

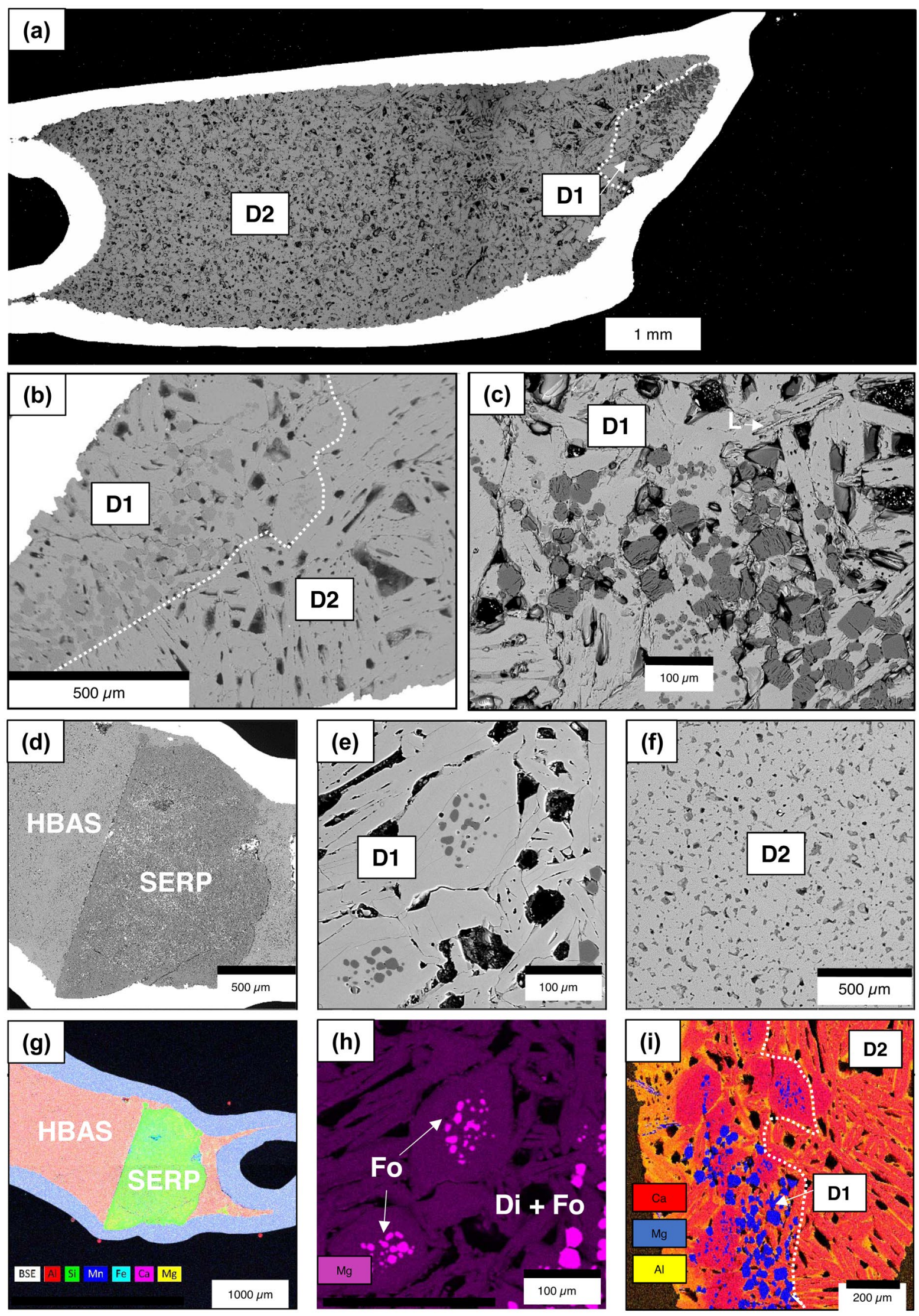
४Fig. 1 (a-f) Backscattered electron images of diopsidite rock experimentally produced during the serpentinite-haplobasaltic glass reaction at $0.2 \mathrm{GPa}, 900{ }^{\circ} \mathrm{C}(\mathrm{P} 40)$ and $1250{ }^{\circ} \mathrm{C}(\mathrm{P} 41$ and $\mathrm{P} 41$ bis samples $)$ for $120 \mathrm{~h}$. In the experimental system at $1250{ }^{\circ} \mathrm{C}$, the final mineral associations are represented by (i) D1: early Al-poor diopsidehosted forsterite inclusions together with (ii) D2: late Al-rich diopside composed by well-crystallized diopsidite with water fluid bubbles. $\mathrm{HBAS}=$ haplobasaltic glass, $\mathrm{SERP}=$ dehydrated serpentinite, $\mathrm{Di}=$ diopside, $\mathrm{Fo}=$ high $\mathrm{Mg}$ olivine and $\mathrm{L}=$ residual melt. (a-c) the P41 sample; (d) P40 sample; (e-f) P41bis sample. (g-i) X-ray mapping for $\mathrm{Al}, \mathrm{Si}, \mathrm{Mn}, \mathrm{Fe}, \mathrm{Ca}$ and $\mathrm{Mg}$ of the experimental diopsidite samples. (g) P40 sample; (h) P41bis sample; mauve color corresponds to the high-Mg olivine inclusions in the D1 diopside. (i) P41 sample. Blue color corresponds to the high-Mg olivine inclusions in the $\mathrm{D} 1$ diopside

systems saturated with water (Fig. 2). Similarly to the haplobasaltic experimental system, any starting composition corresponding to dry anorthite-diopside eutectic composition $\left(\mathrm{Di}_{63} \mathrm{An}_{37}\right)$ at room pressures $(0.1 \mathrm{MPa})$ would result in crystallization of pure diopside at high pressures $(\geq 0.2$ $\mathrm{GPa}$ ) if the system is water-saturated. Silicate melts of composition approaching the pure haplobasaltic systems are not common in nature, nevertheless, natural anorthitediopside associations are documented in ophiolites at
Moho level as described above. The altered lower oceanic crust is regularly enriched in epidote, chlorite (chloriterich epidosite), but also anorthite and high-Ca diopside formed due to intermediate to high temperature alteration (Seyfried et al. 1988; Gillis 1995; McCollum and Shock 1998; Vanko and Laverne 1998; Alt et al. 2010). These altered lower crustal $\mathrm{Ca}-\mathrm{Al}-\mathrm{Mg}$-rich rocks may be formed in the sheeted dyke complex due to hydrothermal fluid circulation through the gabbroic crust. As a result, the $\mathrm{NaCl}$-bearing fluids are strongly enriched in $\mathrm{Ca}, \mathrm{Al}$ and $\mathrm{Si}$ due to the high solubility of anorthite in hydrothermal fluids (Seyfried et al. 1988; Oelkers et al. 1995, 2009). These NaCl-rich fluids (up to $5.6 \mathrm{wt} \% \mathrm{NaCl}$ ) represent 'hot modified seawater' described as inclusions in minerals of anorthitized rocks (Vanko and Laverne 1998). Figure 2 shows an expansion of the diopside crystallization field to Ca-Al-rich compositions in the fluid-saturated systems. Thus, diopside will crystallize from haplobasaltic melt at $\geq 1100^{\circ} \mathrm{C}$ and pressure below $0.5 \mathrm{GPa}$ in the presence of aqueous fluid.

Our model illustrated by Fig. 3 suggests that periodic partial melting of the altered (and enriched in anorthite-diopside) gabbroic crust produces a silicate melt approaching haplobasaltic

Table 3 Chemical composition of mineral and glass phases in the experimental diopsidites produced at $0.2 \mathrm{GPa}$ and $1250{ }^{\circ} \mathrm{C}$

\begin{tabular}{|c|c|c|c|c|c|c|c|c|}
\hline \multirow{3}{*}{$\begin{array}{l}\text { Associatio } \\
\text { Phase }\end{array}$} & \multicolumn{4}{|c|}{ Mineral association D1 } & \multicolumn{4}{|c|}{ Mineral association D2 } \\
\hline & \multicolumn{2}{|c|}{ Olivine (15)* } & \multicolumn{2}{|c|}{$\overline{\text { Diopside } 1(30)^{*}}$} & \multicolumn{2}{|c|}{ Diopside 2 (75)* } & \multicolumn{2}{|c|}{$\begin{array}{l}\text { Residual glass } \\
(4)^{*}\end{array}$} \\
\hline & Average & Error & Average & Error & Average & Error & Average & Error \\
\hline Major and minor oxides (wt\%) & 43.50 & 0.87 & 54.70 & 1.07 & 53.40 & 2.00 & 42.28 & 10.85 \\
\hline $\mathrm{SiO}_{2}$ & bdl & - & bdl & - & bdl & - & bdl & \\
\hline $\mathrm{TiO}_{2}$ & bdl & - & 1.91 & 1.61 & 3.70 & 2.84 & 19.30 & 10.93 \\
\hline $\mathrm{Al}_{2} \mathrm{O}_{3}$ & 0.76 & 0.12 & 0.41 & 0.20 & 0.55 & 0.34 & 1.59 & 0.56 \\
\hline $\mathrm{FeO}$ & bdl & - & bdl & - & bdl & - & bdl & bdl \\
\hline $\mathrm{MnO}$ & 55.16 & 1.50 & 18.80 & 0.70 & 17.97 & 1.20 & 12.62 & 4.65 \\
\hline $\mathrm{CaO}$ & 1.04 & 0.70 & 24.46 & 0.27 & 24.65 & 0.48 & 18.44 & 4.62 \\
\hline $\mathrm{Na}_{2} \mathrm{O}$ & bdl & - & bdl & - & bdl & - & bdl & - \\
\hline $\mathrm{K}_{2} \mathrm{O}$ & bdl & - & bdl & - & bdl & - & bdl & - \\
\hline $\mathrm{Cr}_{2} \mathrm{O}_{3}$ & bdl & - & 0.16 & 0.10 & 0.06 & 0.12 & bdl & - \\
\hline $\mathrm{NiO}$ & 0.21 & 0.06 & bdl & - & bdl & - & bdl & - \\
\hline Total & 100.86 & 1.01 & 100.57 & 0.37 & 100.45 & 0.77 & 94.75 & 5.50 \\
\hline \multicolumn{9}{|l|}{ Mineral and members (mol\%) } \\
\hline Fo & 99.23 & 0.14 & - & - & - & & - & - \\
\hline Wo & - & - & 48.02 & - & 49.22 & - & - & - \\
\hline En & - & - & 51.35 & - & 49.94 & - & - & - \\
\hline Fs & - & - & 0.63 & & 0.84 & - & - & - \\
\hline $\mathrm{Mg} \#$ & 99.23 & 0.14 & 98.76 & 0.62 & 98.27 & 1.21 & 93.34 & 1.25 \\
\hline
\end{tabular}

Errors are quoted at $2 \sigma$ level (standard deviation); $\mathrm{Mg} \#=\mathrm{Mg} /(\mathrm{Mg}+\mathrm{Fe})$; bdl - below detection limit

$F o$ forsterite, Wo wollastonite, En enstatite, $F s$ ferrosilite, $b d l$ values below detection limits

*Backeted numbers correspond to the numbers of EPMA points (P41 and P41bis samples) Average =average value 


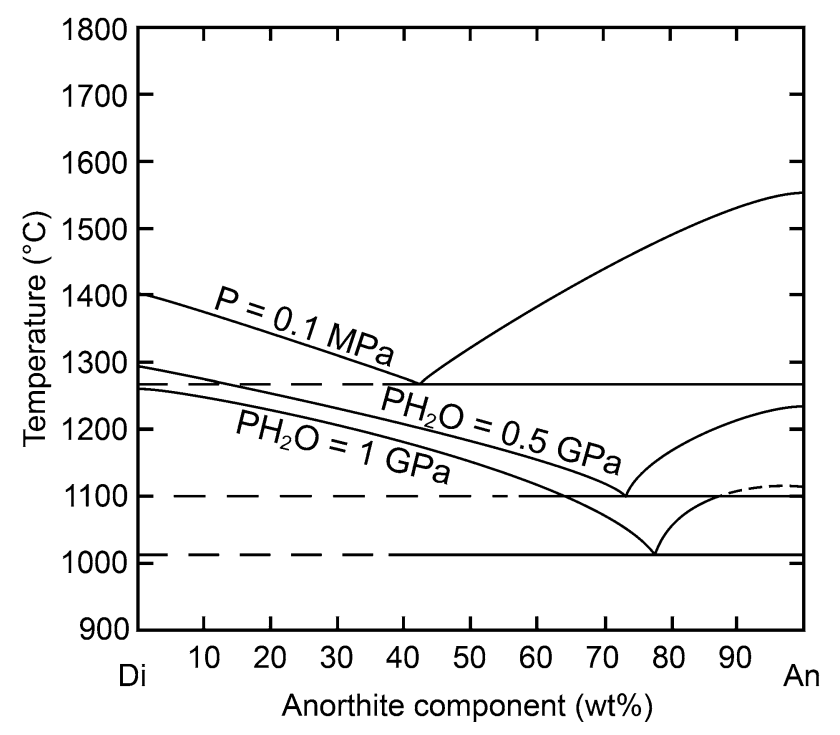

Fig. 2 Diopside (Di) — anorthite (An) phase diagram demonstrating eutectic compositions for three experimental systems (i) anhydrous haplobasaltic melt at $\mathrm{P}=0.1 \mathrm{MPa}$ pressure (marked as $\mathrm{P}=0.1 \mathrm{MPa}$ ); (ii) hydrous system at $0.5 \mathrm{GPa}$ pressure under fluid saturated conditions $\left(\mathrm{P} \mathrm{H}_{2} \mathrm{O}=0.5 \mathrm{GPa}\right)$ and (iii) hydrous system at $1.0 \mathrm{GPa}$ pressure under fluid saturated conditions $\left(\mathrm{P}_{2} \mathrm{O}=1 \mathrm{GPa}\right)$ according to Yoder (1964) and Yoder and Tilley (1962). Expansion of the diopside crystallization field to Ca-Al-rich compositions is remarkable in the fluidsaturated systems
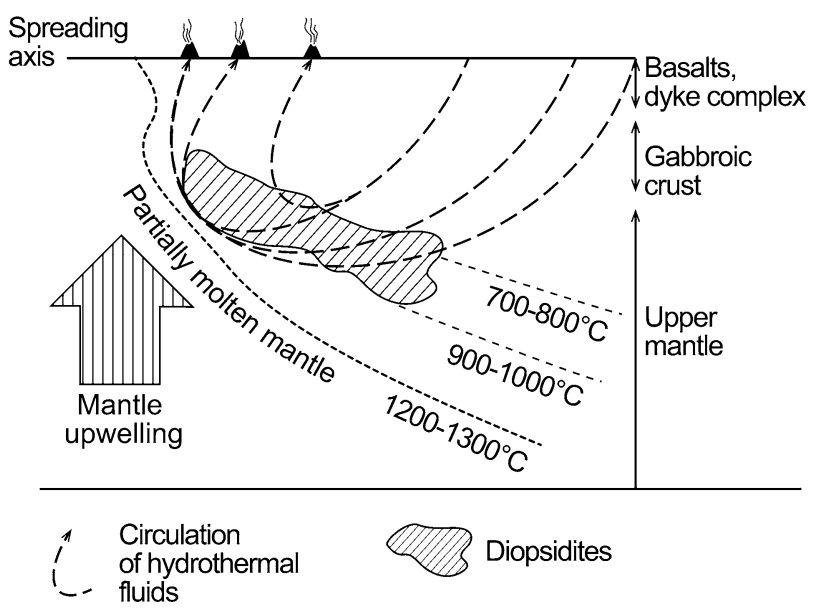

Fig. 3 Simplified model of diopsidite formation in the mantle close to oceanic mantle-crust transition zone. A silicate melt rich in haplobasaltic component is produced due to partial melting of the lower gabbroic crust; it reacts with hydrated peridotite producing diopsidites at depths of $6-10 \mathrm{~km}$ in the oceanic lithospheric mantle. Modified after Python et al. (2007a) and Borisova et al. (2012)

component. The haplobasaltic melt reacts and replaces the mantle peridotite with dykes and veins of forsterite-bearing diopsidites. Indeed, mantle diopsidites are regularly associated with mantle plagiogranites (M. Benoit, personal communication). In fact, the associated mantle plagiogranites have been inferred to form due to fluid-assisted melting of hydrated peridotite owing to the reaction with basaltic melt (Borisova et al. 2021). The process of basaltic melt-peridotite reaction is therefore common in the mantle and the mantle-crust transition zone (Borisova et al. 2020, 2021). The reaction between hydrated peridotite and basaltic melts may happen periodically during the oceanic lithosphere formation. The haplobasaltic melt component, thus, constitutes a missing silicate component necessary for diopside crystallization upon the reaction with peridotite at the level of the oceanic mantle-crust transition zone or even in deeper parts of the lithospheric mantle.

\section{Conclusions}

Synthetic diopsidite was produced experimentally for the first time. In the experimental system, reaction of natural serpentinite with a synthetic haplobasaltic melt (corresponding to the anhydrous anorthite-diopside eutectic at $0.1 \mathrm{MPa}$ ) at $1250^{\circ} \mathrm{C}$ and $0.2 \mathrm{GPa}$ produces two mineral associations represented by (i) Al-poor diopside with high$\mathrm{Mg}$ olivine inclusions and (ii) Al-rich diopside composing well-crystallized diopsidite. We propose a model, where mantle diopsidites are formed near the oceanic mantle-crust transition zone due to reaction of haplobasaltic melt produced via efficient melting of an altered gabbroic crust rich in anorthite and diopside. The generated haplobasaltic melts react with the mantle peridotite at $\geq 1100{ }^{\circ} \mathrm{C}$ and $<0.5 \mathrm{GPa}$ in the presence of high-temperature aqueous fluid to produce veins of forsterite-bearing diopsidites. The process of basaltic melt-hydrated peridotite reaction is common in the oceanic mantle and the mantle-crust transition zone. This reaction (e.g. Eq. 1) may happen periodically during the formation of the oceanic lithosphere at mid-ocean spreading centers.

Acknowledgements The experiments were carried out using an internally heated gas pressure vessel at the Korzhinskii Institute of Experimental Mineralogy (Chernogolovka, Russia). Major element analyses of minerals and glasses and the sample imaging were performed at the Géosciences Environnement Toulouse laboratory (GET) and at the Centre de Microcaractérisation Raimond Castaing (Toulouse, France). Authors thank two anonymous reviewers and journal editor Anton Chakhmouradian for numerous suggestions, which significantly improved the manuscript. This work was supported by the Institut national des Sciences de l'Univers (INSU) foundation, France.

\section{References}

Akizawa N, Arai S (2014) Petrology of mantle diopsidite from Wadi Fizh, northern Oman ophiolite: $\mathrm{Cr}$ and REE mobility by hydrothermal solution. Island Arc 23:312-323

Akizawa N, Arai S, Tamura A, Uesugi J, Python M (2011) Crustal diopsidites from the northern Oman ophiolite: Evidence for 
hydrothermal circulation through suboceanic Moho. J Min Petrol Sci 106:261-266

Alt JC, Laverne C, Coggon RM, Teagle DAH, Banerjee NR, Morgan S, Smith-Duque CE, Harris M, Galli L (2010) Subsurface structure of a submarine hydrothermal system in ocean crust formed at the East Pacific Rise, ODP/IODP Site 1256. Geochem Geophys Geosyst 11:Q10010. https://doi.org/10.1029/2010GC003144

Barth TFW (1962) Theoretical petrology, second edition, J Wiley \& Sons, $416 \mathrm{pp}$

Benne D, Behrens H (2003) Water solubility in haplobasaltic melts. Eur J Mineral 15:803-814

Benoit M, Ceuleneer G, Polvé M (1999) The remelting of hydrothermally altered peridotite at mid-ocean ridges by intruding mantle diapirs. Nature 402:514-518

Borisova AY, Kamenetsky CG, VS, Arai S, Béjina F, Abily B, Bindeman IN, Polvé M, de Parseval P, Aigouy T, Pokrovski GS (2012) A new view on the petrogenesis of the Oman ophiolite chromitites from microanalyses of chromite hosted inclusions. J Petrol 53:2411-2440

Borisova AY, Zagrtdenov NR, Toplis MJ, Ceuleneer G, Safonov O, Shcheka S, Bychkov AY (2020) Hydrated peridotite - basaltic melt interaction Part II: Fast assimilation of serpentinized mantle by basaltic magma. Special Volume on magma-rock and magmamush interactions as fundamental processes of magmatic differentiation. Front. Earth Sci. https://doi.org/10.3389/feart.2020.00084

Borisova AY, Zagrtdenov NR, Toplis MJ, Bohrson WA, Nedelec A, Safonov OG, Pokrovski GS, Ceuleneer G, Melnik OE, Bychkov AY, Gurenko AA, Shcheka S, Terehin A, Polukeev VM, Verlamov DA, Chariteiro KEA, Gouy S, de Parseval P (2021) Hydrated peridotite - basaltic melt interaction Part I: Planetary felsic crust formation at shallow depth. Special Volume on magma-rock and magma-mush interactions as fundamental processes of magmatic differentiation. Frontiers Earth Sci. https://doi.org/10.3389/feart. 2021.640464

Dawson JB, Smith JV (1977) The MARID (mica-amphibole-rutileilmenite-diopside) suite of xenoliths in kimberlite. Geochim Cosmochim Acta 41:309-323. https://doi.org/10.1016/0016-7037(77) 90239-3

Gillis KM (1995) Controls on hydrothermal alteration in a section of fast-spreading oceanic crust. Earth Planet Sci Lett 134:473-489

Irving AJ, Steele IM, Smith JV (1974) Lunar noritic fragments and associated diopside veins. Am Miner 59:1062-1068

Jochum KP, Stoll B, Herwig K, Willbold M, Hofmann AW, Amini M, Aarburg S, Abouchami W, Hellebrand E, Mocek B, Raczek I, Stracke A, Alard O, Bouman C, Becker S, Dücking M, Brätz J, Klemd R, de Bruin D, Canil D, Cornell D, de Hoog CJ, Dalpé C, Danyushevsky L, Eisenhauer A, Gao Y, Snow JE, Groschopf N, Günther D, Latkoczy C, Guillong M, Hauri EH, Höfer HE, Lahaye Y, Horz K, Jacob DE, Kasemann SA, Kent AJR, Ludwig T, Zack T, Mason PRD, Meixner A, Rosner M, Misawa K, Nash BP, Pfänder J, Premo WR, Sun WD, Tiepolo M, Vannucci R, Vennemann T, Wayne D, Woodhead JD (2006) MPI-DING reference glasses for in situ microanalysis: new reference values for element concentrations and isotope ratios. Geochem Geophys Geosyst 7:Q02008
McCollom TM, Shock EL (1998) Fluid-rock interactions in the lower oceanic crust; Thermodynamic models of hydrothermal alteration. J Geophys Res 103:547-575

Oelkers EH, Schott J (1995) Experimental study of anorthite dissolution and the relative mechanism of feldspar hydrolysis. Geochim Cosmochim Acta 59:5039-5053

Oelkers EH, Golubev SV, Chairat C, Pokrovsky OS, Schott J (2009) The surface chemistry of multi-oxide silicates. Geochim Cosmochim Acta 73:4617-4634

Python M, Ceuleneer G, Ishida Y, Barrat JA, Arai S (2007a) Oman diopsidites: a new lithology diagnostic of very high temperature hydrothermal circulation in mantle peridotite below oceanic spreading centers. Earth Planet Sci Lett 255:289-305

Python M, Ishida Y, Ceuleneer G, Arai S (2007b) Trace element heterogeneity in hydrothermal diopside: evidence for Ti depletion and Sr-Eu-LREE enrichment during hydrothermal metamorphism of mantle hazrburgite. J Min Petrol Sci 102:143-149

Rospabé M, Ceuleneer G, Benoit M, Abily B, Pinet P (2017) Origin of the dunitic mantle-crust transition zone in the Oman ophiolite: The interplay between percolating magmas and high-temperature hydrous fluids. Geology 45:471-474

Rospabé M, Ceuleneer G, Granier N, Arai S, Borisova AY (2019) Multi-scale development of a stratiform chromite ore body at the base of the dunitic mantle-crust transition zone (Maqsad diapir, Oman ophiolite): the role of repeated melt and fluid influxes. Lithos 350-351: 105235

Safonov OG, Kosova SA, Van Reenen DD (2014) Interaction of biotiteamphibole gneiss with $\mathrm{H}_{2} \mathrm{O}-\mathrm{CO}_{2}-(\mathrm{K}, \mathrm{Na}) \mathrm{Cl}$ fluids at $550 \mathrm{MPa}$ and 750 and $800^{\circ} \mathrm{C}$ : Experimental study and applications to dehydration and partial melting in the middle crust. J Petrol 55:2419-2456

Seyfried WE, Berndt ME, Seewald JS (1988) Hydrothermal alteration processes at mid-ocean ridges: Constraints from diabase alteration experiment, hot-spring fluids and composition of the oceanic crust. Can Mineral 26:787-804

Vanko DA, Laverne C (1998) Hydrothermal anorthitization of plagioclase within the magmatic/hydrothermal transition at mid-ocean ridges: examples from deep sheeted dikes (Hole 504B, Costa Rica Rift) and a sheeted dike root zone (Oman ophiolite). Earth Planet Sci Lett 162:27-43

Yoder HS (1964) Diopside-anorthite-water at five and ten kilobars and its bearing on explosive volcanism. Carnegie Inst Washington Year Book 64:82-89

Yoder HS, Tilley CE (1962) Origin of basalt magmas: An experimental study of natural and synthetic rock systems. J Petrol 3:342-532

Zagrtdenov NR, Ceuleneer G, Rospabé M, Borisova AY, Toplis MJ, Benoit M, Aigouy T, Gouy S, de Parseval P (2018) Anatomy of a chromitite dyke in the mantle - crust transition zone of the Oman ophiolite. Lithos 312:343-357

Publisher's Note Springer Nature remains neutral with regard to jurisdictional claims in published maps and institutional affiliations. 